\title{
HEALTH PROMOTION PLANNING TO ADDRESS CHILD MALNUTRITION ISSUES IN INDONESIA: A SYSTEMATIC REVIEW
}

\author{
Tasnim \\ School of Health Sciences Mandala Waluya, Kendari
}

\begin{abstract}
Background: Nutritional status of children is one of the major predictors of child sur vival. However, child malnutrition remains a major public health problem in most developing countries, including Indonesia. Understanding the effective health promotion planning is needed to reduce numbers of malnourished children in Indonesia. This study aimed to review systematically health promotion planning to address child malnutrition issues in Indonesia

Subjects and Method: A systematic review was carried out by searching the following databases included proquest and web of sciences. The keywords for this review included health promotion, malnutrition, child, and Indonesia. The inclusion criteria were review, systematic review, clinical review and guidelines. After review process several articles were included in this review.

Results: Implementation of health promotion to overcome child malnutrition in Indonesia should apply the health promotion planning values, including social justice, equity, and mulitiple-setting of actions addressed on social-environmental determinant of health and inequity. The effective health promotion can make difference to individuals and organisations' capacity through developing alliances or partnership.

Conclusion: Implementation of the values and concepts of health promotion planning including equality, participation, empowerment, collaboration, and multi-strategy must be done to overcome child malnutrition in Indonesia.
\end{abstract}

Keywords: health promotion, malnutrition, child, indonesia

\section{Correspondence:}

Tasnim. School of Health Sciences Mandala Waluya, Kendari. Email:

tasnim349@gmail.com. Mobile: o82237658472.

The $5^{\text {th }}$ International Conference on Public Health

Best Western Premier Hotel, Solo, Indonesia, February 13-14, 2019 | 195

https://doi.org/10.26911/theicph.2019.02.31 